\title{
Restoration of T cell tolerance in primary ITP
}

\author{
Xin-guang Liu*, Jun Peng, Ming Hou \\ From New developments in Hematology and Oncology in 2011 \\ Guangzhou, China. 25-26 December 2011
}

Primary immune thrombocytopenia (ITP) has been traditionally thought as an antibody-mediated autoimmune disease involving platelet destruction by macrophages in the reticuloendothelia system. More recently it has become obvious that ITP is a more complex disorder in which $\mathrm{T}$ cell mediated immunity plays important roles in platelet destruction. Antiplatelet autoantibody production is under the control of platelet-specific helper T-cells, and loss of tolerance to self antigen by $\mathrm{T}$ cells is the critical step of the immune dysregulation in ITP. Dendritic cells (DCs) from ITP patients showed enhanced capacity in stimulating autologous T-cell proliferation in the presence of autologous/allogeneic platelets [1], and ITP patients' T cells had elevated IL-2 secretion ability compared with controls $[2,3]$, suggesting increased antiplaltelet T-cell reactivity in ITP. The epitopes that recognize platelet glycoprotein (GP) IIIa on T helper (Th) cells has been determined and mapped by several groups $[4,5]$, thus sheding new lights on the "therapeutic vaccination" approach to reinstate tolerance in ITP. Autoreactive T-cell reactivity against platelet antigen in active ITP patients has been observed at polyclonal as well as oligoclonal levels [6,7]. Our group has demonstrated that blocking the B7-CD28 interaction with CTLA4-Ig/CsA could induce platelet GP-specific T-cell anergy, which could exert suppressive effect on GPreactive $\mathrm{T}$ cells via inducing tolerogenic dendritic cells (DCs) $[8,9]$. It has been well established that apoptotic genes, such as Fas, A20, Bax, Calpastatin, IL2RB, were expressed aberrantly in patients with active ITP $[10,11]$, leading to autoreactive $\mathrm{T}$ cells resistant to activation induced cell death (AICD), which could in turn support the expansion of self-reactive T-cell clones. A loss of resistant to AICD might be an important mechanism for the achievement of remission in ITP. Previous studies have revealed that dexamethasone could suppress $\mathrm{T}$-cell proliferation and induce apoptosis of T-cells in ITP $[11,12]$. In addition, our group has demonstrated that a novel BAFF

\footnotetext{
Department of Hematology, Qilu Hospital, Shandong University, 107 West
} Wenhua Road, Jinan, P. R. China blocking reagent, BR3-Fc, could restore the apoptosis of both B and T cells [13]. Th polarization in ITP has been attributed to increased Th1 [2,14], and Th17 cells [15] or reduced number or function of $\mathrm{CD} 4{ }^{+} \mathrm{CD} 25^{+} \mathrm{Foxp} 3^{+} \mathrm{T}$-regulatory cells (Tregs) $[16,17]$. A parallel body of aberrant cytokine patterns, such as the elevated ratio of interleukin (IL) -18/IL-18 binding protein (BP) [18,19], the increased expression of $\mathrm{B}$ cell activating factor (BAFF) has been reported in active ITP patients [20,21]. High-dose dexamthasone (HD-DXM) could not only restore Th1/Th2 [14] or IL-18/IL-18BP balance [19], but also increase the number of Tregs [16], and inhibit the expression of BAFF [12]. Besides HD-DXM, multiple agents, such as rituximab [22], intravenous immunoglobulin (IVIg) [23], romiplostim, eltrombopag [24] as well as indirubin [25], could increase the number or restore the function of Tregs in ITP. Our recently study showed that GP-specific induced Tregs could be successfully generated de novo from nonregulatory $\mathrm{CD} 4^{+} \mathrm{CD} 25^{-} \mathrm{CD} 45 \mathrm{RA}^{+}$cells and could mediate both antigen-specific and linked suppression of proliferating antiplatelet $\mathrm{CD} 4^{+}$Th cells in vitro, and further research revealed that the de novo expanded Tregs mediated their suppressive effects on $\mathrm{T}$ cells via actually modulating the T-cell stimulatory capacity of DCs [26], thus providing a clue to the potential of producing antigen-specific Tregs from the patients in vitro for the purpose of antigen-targeted cellular immunotherapy. In conclusion, induction of $\mathrm{T}$-cell tolerance may provide a useful strategy for the management of ITP.

Published: 25 April 2012

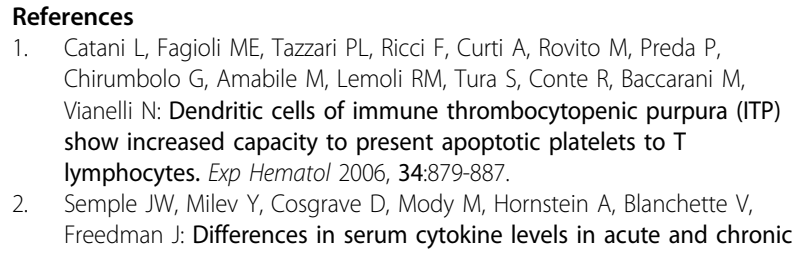

1. Catani L, Fagioli ME, Tazzari PL, Ricci F, Curti A, Rovito M, Preda P, Chirumbolo G, Amabile M, Lemoli RM, Tura S, Conte R, Baccarani M, Vianelli N: Dendritic cells of immune thrombocytopenic purpura (ITP) show increased capacity to present apoptotic platelets to $T$ lymphocytes. Exp Hematol 2006, 34:879-887.

2. Semple JW, Milev Y, Cosgrave D, Mody M, Hornstein A, Blanchette V, Freedman J: Differences in serum cytokine levels in acute and chronic 
autoimmune thrombocytopenic purpura: relationship to platelet phenotype and antiplatelet T-cell reactivity. Blood 1996, 87:4245-4254.

3. Semple JW, Freedman J: Increased antiplatelet T helper lymphocyte reactivity in patients with autoimmune thrombocytopenia. Blood 1991, 78:2619-2625.

4. Kuwana M, Kaburaki J, Kitasato H, Kato M, Kawai S, Kawakami Y, Ikeda Y: Immunodominant epitopes on glycoprotein llb-llla recognized by autoreactive $\mathrm{T}$ cells in patients with immune thrombocytopenic purpura. Blood 2001, 98:130-139.

5. Sukati H, Watson HG, Urbaniak SJ, Barker RN: Mapping helper T-cell epitopes on platelet membrane glycoprotein Illa in chronic autoimmune thrombocytopenic purpura. Blood 2007, 109:4528-4538.

6. Ware RE, Howard TA: Phenotypic and clonal analysis of T lymphocytes in childhood immune thrombocytopenic purpura. Blood 1993, 82:2137-2142.

7. Shimomura T, Fujimura K, Takafuta T, Fujii T, Katsutani S, Noda M, Fujimoto T, Kuramoto A: Oligoclonal accumulation of $\mathrm{T}$ cells in peripheral blood from patients with idiopathic thrombocytopenic purpura. $\mathrm{Br} J$ Haematol 1996, 95:732-7.

8. Peng J, Liu C, Liu D, Ren C, Li W, Wang Z, Xing N, Xu C, Chen X, Ji C, Zhang M, Hou M: Effects of B7-blocking agent and/or CsA on induction of platelet-specific T-cell anergy in chronic autoimmune thrombocytopenic purpura. Blood 2003, 101:2721-2726.

9. Zhang XL, Peng J, Sun JZ, Guo CS, Yu Y, Wang ZG, Chu XX, Hou M: Modulation of immune response with cytotoxic T-lymphocyte-associated antigen 4 immunoglobulin-induced anergic T cells in chronic idiopathic thrombocytopenic purpura. J Thromb Haemost 2008, 6:158-165.

10. Yoshimura C, Nomura S, Nagahama M, Ozaki Y, Kagawa H, Fukuhara S: Plasma-soluble Fas (APO-1, CD95) and soluble Fas ligand in immune thrombocytopenic purpura. Eur J Haematol 2000, 64:219-224.

11. Olsson B, Andersson PO, Jacobsson S, Carlsson L, Wadenvik H: Disturbed apoptosis of T-cells in patients with active idiopathic thrombocytopenic purpura. Thromb Haemost 2005, 93:139-44.

12. Zhu XJ, Shi Y, Sun JZ, Shan NN, Peng J, Guo CS, Qin P, Hou M: High-dose dexamethasone inhibits BAFF expression in patients with immune thrombocytopenia. J Clin Immunol 2009, 29:603-610.

13. Zhu XJ, Shi Y, Peng J, Guo CS, Shan NN, Qin P, Ji XB, Hou M: The effects of BAFF and BAFF-R-Fc fusion protein in immune thrombocytopenia. Blood 2009, 114:5362-5367.

14. Guo C, Chu X, Shi Y, He W, Li L, Wang L, Wang Y, Peng J, Hou M: Correction of Th1-dominant cytokine profiles by high-dose dexamethasone in patients with chronic idiopathic thrombocytopenic purpura. J Clin Immunol 2007, 27:557-562.

15. Zhang J, Ma D, Zhu X, Qu X, Ji C, Hou M: Elevated profile of Th17, Th1 and Tc1 cells in patients with immune thrombocytopenic purpura. Haematologica 2009, 94:1326-1329.

16. Ling Y, Cao X, Yu Z, Ruan C: Circulating dendritic cells subsets and CD4 +Foxp3+ regulatory T cells in adult patients with chronic ITP before and after treatment with high-dose dexamethasome. Eur J Haematol 2007, 79:310-316.

17. Liu B, Zhao H, Poon MC, Han Z, Gu D, Xu M, Jia H, Yang R, Han ZC Abnormality of $\mathrm{CD} 4(+) \mathrm{CD} 25(+)$ regulatory $\mathrm{T}$ cells in idiopathic thrombocytopenic purpura. Eur J Haematol 2007, 78:139-143.

18. Shan NN, Zhu XJ, Peng J, Qin P, Zhuang XW, Wang HC, Hou M: Interleukin 18 and interleukin 18 binding protein in patients with idiopathic thrombocytopenic purpura. Br J Haematol 2009, 144:755-761.

19. Shan NN, Zhu XJ, Wang Q, Wang CY, Qin P, Peng J, Hou M: High-dose dexamethasone regulates interleukin-18 and interleukin-18 binding protein in idiopathic thrombocytopenic purpura. Haematologica 2009, 94:1603-1607.

20. Emmerich F, Bal G, Barakat A, Milz J, Mühle C, Martinez-Gamboa L, Dörner T, Salama A: High-level serum B-cell activating factor and promoter polymorphisms in patients with idiopathic thrombocytopenic purpura. Br J Haematol 2007, 136:309-314

21. Zhou Z, Chen Z, Li H, Chen X, Xu J, Gu D, Du W, Zheng C, Zhang L, Huang $Y$, Ren $Q$, Yang R: BAFF and BAFF-R of peripheral blood and spleen mononuclear cells in idiopathic thrombocytopenic purpura. Autoimmunity 2009, 42:112-119.

22. Stasi R, Cooper N, Del Poeta G, Stipa E, Laura Evangelista M, Abruzzese E, Amadori S: Analysis of regulatory T-cell changes in patients with idiopathic thrombocytopenic purpura receiving $B$ cell-depleting therapy with rituximab. Blood 2008, 112:1147-1150.
23. De Groot AS, Moise L, McMurry JA, Wambre E, Van Overtvelt L, Moingeon P, Scott DW, Martin W: Activation of natural regulatory T cells by lgG Fc-derived peptide "Tregitopes". Blood 2008, 112:3303-3311.

24. Bao W, Bussel JB, Heck S, He W, Karpoff M, Boulad N, Yazdanbakhsh K. Improved regulatory T-cell activity in patients with chronic immune thrombocytopenia treated with thrombopoietic agents. Blood 2010, 116:4639-4645.

25. Zhang A, Qu Y, Zhang B, Zhang L, Zeng C, Peng J, Ji X, Hou M, Zhao Y: The different effects of indirubin on effector and $\mathrm{CD} 4+\mathrm{CD} 25+$ regulatory T cells in mice: potential implication for the treatment of autoimmune diseases. J Mol Med 2007, 85:1263-1270.

26. Zhang XL, Peng J, Sun JZ, Liu JJ, Guo CS, Wang ZG, Yu Y, Shi Y, Qin P Li SG, Zhang LN, Hou M: De novo induction of platelet-specific CD4(+) CD25(+) regulatory T cells from CD4(+)CD25(-) cells in patients with idiopathic thrombocytopenic purpura. Blood 2009, 113:2568-2577.

doi:10.1186/1756-8722-5-S1-A5

Cite this article as: Liu et al:: Restoration of T cell tolerance in primary ITP. Journal of Hematology \& Oncology 2012 5(Suppl 1):A5.

\section{Submit your next manuscript to BioMed Central and take full advantage of:}

- Convenient online submission

- Thorough peer review

- No space constraints or color figure charges

- Immediate publication on acceptance

- Inclusion in PubMed, CAS, Scopus and Google Scholar

- Research which is freely available for redistribution
C Biomed Central 